\title{
Effect of Student Activity Participation on Accounting Education
}

\author{
Yeon-Hee Park ${ }^{1}$, Tae-Young Paik ${ }^{2}$ and Jeong-Ho Koo ${ }^{3, *}$ \\ 1 Department of Accounting, Kongju National University, Kongju 32588, Korea \\ 2 School of Business, Sungkyunkwan University, Seoul 03063, Korea \\ 3 Department of Business Administration, Kumoh National Institute of Technology, Gumi 39177, Korea \\ * Correspondence: jhk2001@kumoh.ac.kr; Tel.: +82-54-478-7840
}

Received: 3 June 2019; Accepted: 24 June 2019; Published: 27 June 2019

\begin{abstract}
Accounting education focuses on delivering knowledge to students. Most student are passive, behaving as bystanders or listeners in lecturer-oriented learning. However, student-centered learning requires active and positive engagement from students to generate effective learning. Board games represent a key driving tool in inducing student participation and interest in active learning. This study investigates whether the active participation of students in class activities has positive effects on accounting education. Specifically, it tests whether active student involvement in board game activities in introductory accounting courses contributes to effective learning. There were a few key findings. Firstly, the more actively that students participate in the game, the higher their favorable changes are in terms of perception of accounting. Secondly, the higher their positive perceptions are, the higher the effects of accounting education are. These results imply that the active involvement of learners is a precondition for the effect of accounting education activities, and that positive perception is a mediator for learning effects.
\end{abstract}

Keywords: accounting education; board game; active learning; team activities; learning effects

\section{Introduction}

Traditional study sheds light on the effects of education itself as opposed to the needs and interests of students. Student-oriented learning enhances students' positive attitudes, and it requires the active participation of students through problem-solving processes, whereby they meet issues in projects or real-world situations [1-3]. However, for a long time, most textbooks on accounting principles explained the accounting concepts and technical terms (for example, debit and credit) of the double entry system from the beginning. This approach makes many students lose interest in accounting very quickly.

This paper studies the effectiveness of active learning based on a board game. Specifically, it shows that the more students actively participate in the activities, the more effective their learning in introductory accounting is. Some accounting professors recently tried increasing students' attention, interest, and understanding by using games as learning activities [4-8].

For active learning to be effective, active student participation is a crucial prerequisite. In this study, students were asked to play a board game in teams, record transactions, and prepare financial statements from the game. This study empirically shows that active participation in game-based activities leads to positive perceptions of accounting and finally to effective accounting education.

One implication of the results is that instructors need to create learning environments where students actively participate in activities such as game playing, in or out of classes, for effective learning. The results also imply that some kind of student involvement in activities is desired, even considering the newfound popularity of online accounting classes. 
This paper is organized as follows: Section 2 summarizes prior studies on active learning in accounting education and board game activities used. Section 3 contains the hypotheses and empirical models for analysis. Section 4 explains the research design of variables and samples. Section 5 reports the empirical results based on the survey. Section 6 concludes the paper.

\section{Prior Literature and Board Game Activities}

\subsection{Prior Literature}

Financial accounting education that focuses on technical details leads students to perceive accounting as difficult and boring, which results in them losing interest in learning the subject [9]. Most college students are not exposed to accounting in high school, and its unfamiliar terms discourage them from learning accounting [10].

Hence, many prior studies reported that various methods and efforts to enhance student interest and class participation are needed, and that cultivating the ability to apply accounting knowledge to real settings is more important than simply memorizing accounting rules without any purpose $[4,8,11]$.

It is important to change students' negative perception of accounting since their perceptions affect not only their learning and performance, but also their academic and career choices [12]. Various types of active learning intended to overcome problems in traditional accounting teaching methods were tried in order to reduce the negative perception of accounting. Many different kinds of activities such as special lectures, media watching, games, role playing, quiz shows, singing auditions, newsletters, and team projects were introduced to make students interested and get them involved in accounting education $[4-8,10,13,14]$.

A board game similar to Monopoly is used in introductory accounting courses [5-8]. Prior studies explained how to use the board game effectively in classes, but did not empirically show that the game is in fact effective for learning accounting, except for that by Park et al. (2016) [7]. Park et al. (2016) [7] reported survey results from students who used the board game for their accounting principles courses. They showed that the board game was in fact a useful and effective tool for accounting education, documenting that the average answer scores were significantly favorable in all areas for motivation, participation, applicability, satisfaction, perception, and learning. This work, on the other hand, investigates the relationships among the various effects of board game activities that ultimately lead to learning effects.

\subsection{Board Game Activities}

The Blue Marble, which is a Korean board game very similar to Monopoly, was played by teams in introductory accounting courses. In the game, players bought land, built hotels and buildings in major world cities, and collected rent from other players visiting their properties.

Two to four two-person teams played games against one another sitting around a big table. One person on each team made business decisions on purchasing land, building hotels, borrowing money, and so on. The other kept their transaction records based on the accounting equation.

A minimum of two rounds of the game were played for three hours each. Students could easily understand the idea of the accounting cycle by playing two rounds of continued board games. In the first round, all transactions were cash-based, while credit-based transactions were introduced for accrual basis accounting in the second round. General journals and general ledgers could be used in the additional third round.

Prior to game playing, only a simple explanation of assets, liabilities, owner's equity, revenues, and expenses was given. Further discussion of these accounts was avoided before the games were played. Students had to learn how to use the worksheet based on the accounting equation, Assets $=$ Liabilities + Owner's equity, to record all transactions they had while playing the games.

At the end of each round, students firstly calculated the ending balances of all accounts on the worksheets. It was then checked whether the accounting equation held with the ending balances of all 
accounts on the worksheet. Financial statements of income statements, balance sheets, and cash flow statements were finally made using the numbers on the worksheet and templates provided by the instructors. An example of how to record transactions on the worksheet is shown in Table 1.

Table 1. Recording transactions on the worksheet in the board game.

\begin{tabular}{|c|c|c|c|}
\hline No & Board Game Events & $\begin{array}{l}\text { Accounting } \\
\text { Transactions }\end{array}$ & Entries \\
\hline 1 & Divide money among teams & $\begin{array}{l}\text { Pay capital in business } \\
\text { for cash }\end{array}$ & $\begin{array}{l}\text { A: }(+) \text { cash; OE: }(+) \text { paid } \\
\text { in capital }\end{array}$ \\
\hline 2 & $\begin{array}{l}\text { Buy land on the board where you arrive } \\
\text { for the first time }\end{array}$ & Buy lands for cash & A: (+) lands; A: (-) cash \\
\hline 3 & $\begin{array}{l}\text { Add buildings on your land by paying } \\
\text { cash to the bank }\end{array}$ & $\begin{array}{l}\text { Acquire buildings for } \\
\text { cash }\end{array}$ & $\begin{array}{l}\text { A: }(+) \text { buildings; } \mathrm{A}:(-) \\
\text { cash }\end{array}$ \\
\hline 4 & $\begin{array}{l}\text { Receive rental fees from other players } \\
\text { visiting your properties }\end{array}$ & $\begin{array}{l}\text { Receive rental revenue } \\
\text { for cash }\end{array}$ & $\begin{array}{c}\text { A: }(+) \text { cash; } R:(+) \text { rental } \\
\text { revenue }\end{array}$ \\
\hline
\end{tabular}

A: assets; OE: owner's equity; R: revenue.

\section{Hypotheses and Models}

\subsection{Hypotheses}

In traditional lecture-based learning, instructors mainly deliver lectures while students passively take classes as bystanders [15]. If some activities are incorporated in classes, students can be involved as active class participants. They can execute analyses from various perspectives with comprehensive thinking, thereby developing critical skills which cannot be obtained in one-sided lectures [16].

Using team activities in cooperative learning environments results in students feeling more responsible for activities and more involved in learning by being empowered in the learning processes [17]. Kwon and Woo (2018) [18] presented that cooperation in team projects fostered higher outcomes in business education. Park et al. (2016) [7] reported that board game activities positively changed students' perception of accounting.

To actively engage in team activities through active learning, students must be given decision-making autonomy for solving problems by themselves. Even those who have a negative prejudice toward accounting can become naturally interested in accounting subjects by actively participating in team activities.

If instructors create environments requiring active student involvement in team activities, students will obtain a positive perception of accounting as a result. Therefore, we set the first hypothesis expecting that board game activities that ask for active participation by students will positively change their perception of accounting.

Hypothesis 1: In active learning, active participation in team activities creates a positive perception of accounting.

Many prior studies documented that student participation in various team activities had positive impacts on accounting education [10,14,15,19-21] Braun and Sellers (2012) [10] reported that in-class quizzes induced students to arrive on time and to participate in class discussion. Hwang et al. $(2005 ; 2008)[15,19]$ showed that cooperative learning in student teams resulted in higher test scores than traditional lecture-style learning in financial accounting.

Mladenovic (2000) [12] argued that it is important to change students' negative perceptions since students' perceptions influence their learning approaches, which in turn affect learning outcomes. The second hypothesis empirically tests the relationship between students' perceptions and learning.

Hypothesis 2: Under active learning, a positive perception of accounting improves accounting learning. 


\subsection{Research Model}

According to prior studies, positive learning effects appear when students actively participate in class preparation and devote enough time and effort for learning. Under active learning, if students take active part in team activities, they will gain positive perceptions of the learning objectives and achieve higher learning effects.

This paper uses the research model shown in Figure 1 to empirically test the relationships among active participation, positive perceptions, and effective learning. Regressions of the two steps are used to determine if positive perception plays the role of mediator in effective learning.

Regressions by steps in Cohen et al. (2003) [22] were used to check the significance of the path in the first step. In these regressions, a significant relationship between the independent variable of active participation and the dependent variable of introductory accounting learning (active participation $\rightarrow$ learning) should be shown. The relationship between the independent variable of active participation and the mediating variable of positive perception (active participation $\rightarrow$ positive perception) and the relationship between the mediating variable of positive perception and the dependent variable of introductory accounting learning (positive perception $\rightarrow$ learning) should also be significant.

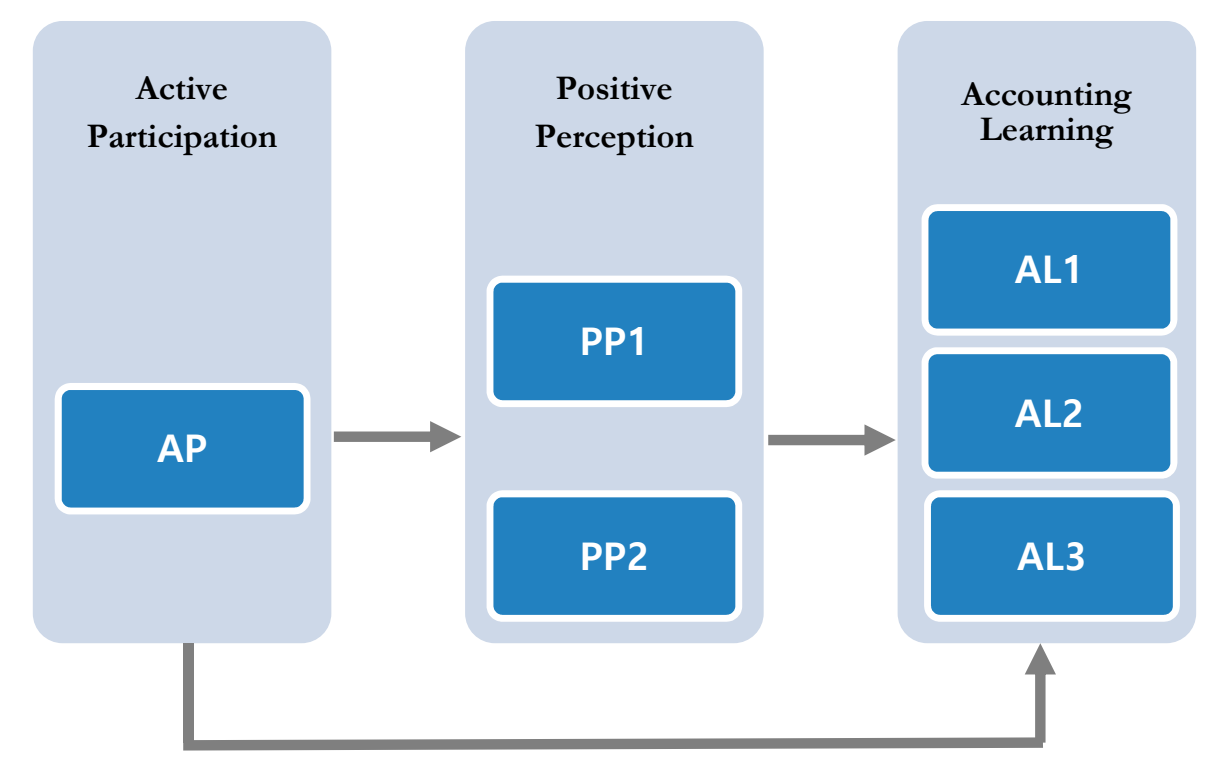

AP: Active participation

PP1: Positive perception of relevance about game and learning

PP2: Positive perception of learning

AL2: Accounting systems learning

AL1: Accounting concepts learning

AL3: Accounting reports learning

Figure 1. Research model.

The regression in the second step has the independent, mediating, and dependent variables together. If the coefficient of the independent variable is no longer significant, this implies that there is an effect of the mediating variable. If the coefficient of the independent variable is significant and that of the mediating variable is as significant as that in the step 1 regression, then there is no effect of the mediating variable. If the coefficient of the mediating variable is smaller or less significant than that in the step 1 regression, then there is a partial effect of the mediating variable.

This research had the independent variable of active participation, the mediating variable of positive perception, and the dependent variable of accounting learning. The regressions were as follows:

$<$ Step 1>

$\mathrm{AL}=\alpha_{0}+\beta_{0} \mathrm{G}+\beta_{1} \mathrm{Y}+\beta_{2} \mathrm{AP},(1)$ 


$$
\begin{aligned}
& \mathrm{PP}=\alpha_{0}+\beta_{0} \mathrm{G}+\beta_{1} \mathrm{Y}+\beta_{2} \mathrm{AP},(2) \\
& \mathrm{AL}=\alpha_{0}+\beta_{0} \mathrm{G}+\beta_{1} \mathrm{Y}+\beta_{2} \mathrm{PP},(3)
\end{aligned}
$$

Where $\mathrm{PP}$ is positive perception, $\mathrm{G}$ is gender, $\mathrm{Y}$ is college year, $\mathrm{AP}$ is active participation, and $\mathrm{AL}$ is accounting learning;

$<$ Step 2>

$$
\mathrm{AL}=\alpha_{0}+\beta_{0} \mathrm{G}+\beta_{1} \mathrm{Y}+\beta_{2} \mathrm{PP}+\beta_{3} \text { AP. (4) }
$$

\section{Research Design}

\subsection{Variables}

This paper operationally defines the main variables of active participation, positive perception, and accounting learning based on Park et al. (2016) [7], and measures them using a five-point Likert scale as described below.

Firstly, active participation represents how actively students participated and were involved in class activities. This included survey questions on how sincerely and actively they carried out their team roles and listened to the opinions of others.

Secondly, positive perception has two components: positive perception of accounting itself, and positive perception of the relationship between the games played and accounting learning. The former had questions on the ease, interests, and perceptions of accounting. The latter had questions on the meaningfulness, relevance, and usefulness of game activities.

Thirdly, accounting learning shows how effectively game activities helped students understand the concepts of assets, liabilities, equity, revenue, and expenses and how making the financial statements helped understand accounting transactions and the accounting equation. Accounting learning had three subgroups of accounting concepts (AL1), accounting systems (AL2), and accounting reports (AL3). AL1 questions asked how effectively the basic concepts of assets, liabilities, equity, revenue, and expenses and the main accounts of cash, tangible assets, borrowing, and interests were understood. AL2 consisted of questions about the effective understanding of transactions, bookkeeping, and the accounting equation. Finally, AL3 included questions on the usefulness of game activities in preparing income statements and balance sheets.

\subsection{Samples}

This paper was designed in an undergraduate course incorporating an accounting principles course at two universities in Korea. The accounting principles course is the most basic and mandatory subject in university. Students in this course were a mix of first-time students who were new to accounting principles and students who were retaking the course. In this paper, students played the board games before the typical lecture-type classes for the first two weeks of the course. Because most students did not have any knowledge about accounting, with this activity, they could participate in the class during the first two weeks. After the game, they would be able to easily understand basic accounting concepts and accounting cycles from recording transactions to reporting financial statements within the remaining 14 weeks of the course.

The samples for the paper were collected from a student survey in two sections of accounting principles at the two universities in the fall of 2015. This study used 94 samples from the survey. Table 2 shows the distribution of the 94 samples. In Table 2, of the 94 respondents, $53.2 \%$ were male and $46.8 \%$ were female, mitigating the bias dependent on gender. Of the respondents, $83 \%$ were taking the course for the first time and $76.6 \%$ were freshmen. This implies that we can expect an unbiased effect of the board game on accounting education. 
Table 2. Sample distribution $(n=94)$. M-male; F-female.

\begin{tabular}{ccccccccc}
\hline & \multicolumn{2}{c}{ Gender } & \multicolumn{2}{c}{ New or Retake } & \multicolumn{4}{c}{ College Year } \\
\cline { 2 - 9 } & $\mathbf{M}$ & $\mathbf{F}$ & New & Retake & Freshman & Sophomore & Junior & Senior \\
\hline $\begin{array}{c}\text { Number of } \\
\text { students }(\%)\end{array}$ & 50 & 44 & 78 & 16 & 72 & 13 & 6 & 3 \\
\hline
\end{tabular}

\section{Results}

\subsection{Descriptive Statistics}

A factor analysis was used to show the construct validity of the variables based on the survey questions. This paper carried out a factor analysis by dividing questions into three categories of active participation, positive perception, and learning effects based on the similarity of conceptions measured following Choi and Park (2010) [23]. Varimax rotation of the factor analysis generated six variables of active participation (AP), positive perception of relevance about game and learning (PP1), positive perception of learning (PP2), accounting concepts learning (AL1), accounting systems learning (AL2), and accounting reports (AL3). All of these variables were reliable with Cronbach's alpha greater than 0.9. This means that the average scores of the questions consisting of the six variables could be used for empirical tests [23].

Table 3 shows the descriptive statistics of the variables based on the five-point Likert scale scores of related questions. The means were around four, except for accounting systems learning, which had a mean around two.

Table 3. Descriptive statistics and Cronbach's alpha.

\begin{tabular}{cccccc}
\hline Variables & Cronbach's Alpha & Mean & SD & Min & Max \\
\hline Active participation (AP) & 0.927 & 4.160 & 0.777 & 2 & 5 \\
\hline $\begin{array}{c}\text { Positive perception of relevance about } \\
\text { game and learning (PP1) }\end{array}$ & 0.918 & 3.902 & 0.718 & 2 & 5 \\
\hline Positive perception of learning (PP2) & 0.912 & 4.011 & 0.694 & 2 & 5 \\
\hline Accounting concepts learning (AL1) & 0.925 & 3.845 & 0.660 & 2 & 5 \\
\hline Accounting systems learning (AL2) & 0.920 & 2.037 & 0.383 & 1 & 3 \\
\hline Accounting reports learning (AL3) & 0.938 & 3.667 & 0.771 & 2 & 5 \\
\hline
\end{tabular}

Table 4 shows that all variables were correlated with one another.

Table 4. Correlations.

\begin{tabular}{cccccc}
\hline Variables & AP & PP1 & PP2 & AL1 & AL2 \\
\hline AP & 1 & & & & \\
PP1 & $0.802^{* * *}$ & 1 & & & \\
PP2 & $0.812^{* * *}$ & $0.817^{* * *}$ & 1 & & \\
AL1 & $0.623^{* * *}$ & $0.709^{* * *}$ & $0.739^{* * *}$ & 1 & \\
AL2 & $0.735^{* * *}$ & $0.782^{* * *}$ & $0.815^{* * *}$ & $0.686^{* * *}$ & 1 \\
AL3 & $0.463^{* * *}$ & $0.591^{* * *}$ & $0.677^{* * *}$ & $0.739^{* * *}$ & $0.625^{* * *}$ \\
\hline
\end{tabular}

AP: active participation; PP1: positive perception of relevance about game and learning; PP2: positive perception of learning; AL1: accounting concepts learning; AL2: accounting systems learning; AL3: accounting reports learning. $*, * *, * *$ Significant at the $10 \%, 5 \%$, and $1 \%$ levels, respectively.

\subsection{Hypotheses Tests}

This paper adopted the regressions of multiple steps to test the hypotheses [22]. In the first step, the three relationships between the independent variable (AP) and dependent variables (AL1, AL2, and 
AL3), between the independent variable (AP) and mediating variables (PP1 and PP2), and between the mediating variables (PP1 and PP2) and dependent variables (AL1, AL2, and AL3) were investigated, and the results are reported in Tables 5-7.

Table 5. Effect of active participation on accounting learning.

\begin{tabular}{ccccccc}
\hline \multirow{2}{*}{ Variables } & \multicolumn{2}{c}{ AL1 } & \multicolumn{2}{c}{ AL2 } & \multicolumn{2}{c}{ AL3 } \\
\cline { 2 - 7 } & Coefficient & $t$-Stat & Coefficient & $\boldsymbol{t}$-Stat & Coefficient & $t$-Stat \\
\hline Intercept & $16.733^{* * *}$ & 5.09 & $2.696^{* * *}$ & 3.63 & $3.105^{* * *}$ & 3.15 \\
Gender & $-1.946^{* *}$ & -2.01 & $-0.423^{*}$ & -1.93 & -0.024 & -0.08 \\
College year & 0.563 & 0.87 & 0.024 & 0.16 & 0.256 & 1.32 \\
AP & $2.391^{* * *}$ & 7.69 & $0.725^{* * *}$ & 10.32 & $0.469 * * *$ & 5.03 \\
\hline Adjusted $R^{2}$ & \multicolumn{2}{c}{0.405} & \multicolumn{2}{c}{0.543} & \multicolumn{2}{c}{0.204} \\
\hline
\end{tabular}

AP: active participation; AL1: accounting concepts learning; AL2: accounting systems learning; AL3: accounting reports learning. ${ }^{*}, * * * *$ Significant at the $10 \%, 5 \%$, and $1 \%$ levels, respectively.

As shown in Table 5, active participation had a statistically significant positive influence on the three kinds of accounting learning, i.e., concepts, systems, and reports.

Table 6 shows that the active participation (AP) of students favorably changed their perception of accounting, reporting significantly positive coefficients of AP.

Table 7 documents the positive effects of perception change (mediating variable) on accounting learning (dependent variable) in the three categories.

Table 6. Effect of active participation on positive perception.

\begin{tabular}{ccccc}
\hline \multirow{2}{*}{ Variables } & \multicolumn{2}{c}{ PP1 } & \multicolumn{2}{c}{ PP2 } \\
\cline { 2 - 5 } & Coefficient & $t$-Stat & Coefficient & $t$-Stat \\
\hline Intercept & $2.282^{*}$ & 1.88 & $3.015^{* * *}$ & 3.42 \\
Gender & 0.037 & 0.1 & 0.007 & 0.03 \\
College year & $0.597^{* *}$ & 2.5 & 0.070 & 0.4 \\
AP & $1.497^{* * *}$ & 13.06 & $1.073^{* * *}$ & 12.86 \\
\hline Adjusted $R^{2}$ & & 0.65 & \multicolumn{2}{c}{0.639} \\
\hline
\end{tabular}

AP: active participation; PP1: positive perception of relevance about game and learning; PP2: positive perception of learning. ${ }^{*}, * *, * *$ Significant at the $10 \%, 5 \%$, and $1 \%$ levels, respectively.

Table 7. Effect of positive perception on accounting learning.

\begin{tabular}{ccccccc}
\hline \multirow{2}{*}{ Variables } & \multicolumn{2}{c}{ AL1 } & \multicolumn{2}{c}{ AL2 } & \multicolumn{2}{c}{ AL3 } \\
\cline { 2 - 7 } & $\begin{array}{c}\text { Coefficient } \\
(t \text {-Stat })\end{array}$ & $\begin{array}{c}\text { Coefficient } \\
(t \text {-Stat })\end{array}$ & $\begin{array}{c}\text { Coefficient } \\
(t \text {-Stat })\end{array}$ & $\begin{array}{c}\text { Coefficient } \\
(t \text {-Stat })\end{array}$ & $\begin{array}{c}\text { Coefficient } \\
(t \text {-Stat })\end{array}$ & $\begin{array}{c}\text { Coefficient } \\
(t \text {-Stat })\end{array}$ \\
\hline \multirow{2}{*}{ Intercept } & $\begin{array}{c}15.112^{* * *} \\
\text { (5.27) }\end{array}$ & $\begin{array}{c}15.112^{* * *} \\
(3.83)\end{array}$ & $\begin{array}{c}2.555^{* * *} \\
(3.93)\end{array}$ & $\begin{array}{c}1.485^{* *} \\
(2.28)\end{array}$ & $\begin{array}{c}2.344^{* * *} \\
(2.68)\end{array}$ & 0.880 \\
\multirow{2}{*}{ Gender } & $-2.031^{* *}$ & $-2.031^{* *}$ & $-0.453^{* *}$ & $-0.438^{* *}$ & -0.035 & -0.016 \\
& $(-2.33)$ & $(-2.39)$ & $(-2.29)$ & $(-2.39)$ & $(-0.13)$ & $(-0.07)$ \\
\hline \multirow{2}{*}{ College year } & -0.338 & -0.338 & $-0.240^{* *}$ & -0.028 & 0.068 & 0.230 \\
& $(-0.58)$ & $(-0.72)$ & $(-1.8)$ & $(-0.23)$ & $(0.38)$ & $(1.43)$ \\
\hline \multirow{2}{*}{ PP1 } & $1.465^{* * *}$ & & $0.422^{* * *}$ & & $0.316^{* * *}$ & \\
& $(9.66)$ & & $(12.26)$ & & $(6.83)$ & \\
\hline \multirow{2}{*}{ PP2 } & & $2.128^{* * *}$ & & $0.609 * * *$ & & $0.510^{* * *}$ \\
& & $(10.65)$ & & $(13.78)$ & & $(8.79)$ \\
\hline Adjusted $R^{2}$ & 0.516 & 0.564 & 0.627 & 0.68 & 0.329 & 0.453 \\
\hline
\end{tabular}

PP1: positive perception of relevance about game and learning; PP2: positive perception of learning; AL1: accounting concepts learning; AL2: accounting systems learning; AL3: accounting reports learning. ${ }^{*}, * * * * *$ Significant at the $10 \%, 5 \%$, and $1 \%$ levels, respectively. 
Tables 8-10 show the results of the second step regressions with the independent, mediating, and dependent variables together. The mediating effect of PP was confirmed if the coefficient of the independent variable, AP, was insignificant or smaller than that in Table 5 without the mediating variable.

In Table 8, PP1 and PP2 had significant positive effects on AL1 but AP did not. This implies that PP had a mediating effect between participation and learning.

Table 8. Effect of positive perception on accounting concepts learning-mediating effect.

\begin{tabular}{ccccccc}
\hline \multirow{2}{*}{ Variables } & \multicolumn{6}{c}{ Accounting Concepts Learning (AL1) } \\
\cline { 2 - 7 } & Coefficient & $\boldsymbol{t}$-Stat & Coefficient & $\boldsymbol{t}$-Stat & Coefficient & $\boldsymbol{t}$-Stat \\
\hline Intercept & $13.965^{* * *}$ & 4.63 & $10.875^{* * *}$ & 3.63 & $10.687^{* * *}$ & 3.67 \\
Gender & $-1.991^{* *}$ & -2.29 & $-1.960^{* *}$ & -2.36 & $-1.982^{* *}$ & -2.46 \\
College year & -0.162 & -0.27 & 0.427 & 0.77 & 0.047 & 0.08 \\
PP1 & $1.213^{* * *}$ & 4.69 & & & $0.689^{* *}$ & 2.52 \\
PP2 & & & $1.943^{* * *}$ & 5.74 & $1.484^{* * *}$ & 3.94 \\
AP & 0.575 & 1.2 & 0.306 & 0.68 & -0.233 & -0.48 \\
\hline Adjusted $R^{2}$ & \multicolumn{7}{c}{0.519} & \multicolumn{2}{c}{0.562} & \multicolumn{2}{c}{0.587} \\
\hline
\end{tabular}

AP: active participation; PP1: positive perception of relevance about game and learning; PP2: positive perception of learning; AL1: accounting concepts learning. ${ }^{*}, * * * * *$ Significant at the $10 \%, 5 \%$, and $1 \%$ levels, respectively.

In Table 9, when only one of PP1 and PP2 was included in the model, the AP coefficient $(0.274$ and 0.204, respectively) was significant but smaller than that (0.725) in Table 5. When both PP1 and PP2 were included, AP was no longer significant. Hence, the mediating effect of PP on AL2 was confirmed.

In Table 10, for AL3, the coefficient of AP was either insignificant or smaller than that in Table 5, implying a mediating effect.

Table 9. Effect of positive perception on accounting systems learning-mediating effect.

\begin{tabular}{ccccccc}
\hline \multirow{2}{*}{ Variables } & \multicolumn{6}{c}{ Accounting Systems Learning (AL2) } \\
\cline { 2 - 7 } & Coefficient & $\boldsymbol{t}$-Stat & Coefficient & $\boldsymbol{t}$-Stat & Coefficient & $\boldsymbol{t}$-Stat \\
\hline Intercept & $2.009^{* * *}$ & 3.03 & $1.234^{*}$ & 1.9 & $1.187^{*}$ & 1.9 \\
Gender & $-0.434^{* *}$ & -2.26 & $-0.426^{* *}$ & -2.37 & $-0.432^{* *}$ & -2.5 \\
College year & -0.156 & -1.18 & -0.010 & -0.08 & -0.104 & -0.86 \\
PP1 & $0.301^{* * *}$ & 5.3 & & & $0.170^{* * *}$ & 2.9 \\
PP2 & & & $0.485^{* * *}$ & 6.61 & $0.372^{* * *}$ & 4.62 \\
AP & $0.274^{* * *}$ & 2.61 & $0.204^{* *}$ & 2.09 & 0.071 & 0.69 \\
\hline Adjusted $R^{2}$ & \multicolumn{7}{c}{0.65} & \multicolumn{2}{c}{0.692} & \multicolumn{2}{c}{0.716} \\
\hline
\end{tabular}

AP: active participation; PP1: positive perception of relevance about game and learning; PP2: positive perception of learning; AL2: accounting systems learning. ${ }^{*}, * *, * *$ Significant at the $10 \%, 5 \%$, and $1 \%$ levels, respectively.

Table 10. Effect of positive perception on accounting reports learning-mediating effect.

\begin{tabular}{ccccccc}
\hline \multirow{2}{*}{ Variables } & \multicolumn{6}{c}{ Accounting Reports Learning (AL3) } \\
\cline { 2 - 7 } & Coefficient & $\boldsymbol{t}$-Stat & Coefficient & $\boldsymbol{t}$-Stat & Coefficient & $\boldsymbol{t}$-Stat \\
\hline Intercept & $2.370^{* * *}$ & 2.55 & 1.156 & 1.34 & 1.123 & 1.32 \\
Gender & -0.036 & -0.13 & -0.029 & -0.12 & -0.033 & -0.14 \\
College year & 0.064 & 0.34 & 0.211 & 1.32 & 0.143 & 0.87 \\
PP1 & $0.322^{* * *}$ & 4.05 & & & 0.123 & 1.53 \\
PP2 & & & $0.646^{* * *}$ & 6.66 & $0.564^{* * *}$ & 5.12 \\
AP & -0.013 & -0.09 & $-0.224^{*}$ & -1.74 & $-0.321 * *$ & -2.25 \\
\hline Adjusted $R^{2}$ & \multicolumn{2}{c}{0.322} & \multicolumn{2}{c}{0.465} & \multicolumn{2}{c}{0.473} \\
\hline
\end{tabular}

AP: active participation; PP1: positive perception of relevance about game and learning; PP2: positive perception of learning; AL3: accounting reporting learning. ${ }^{*}, * *, * * *$ Significant at the $10 \%, 5 \%$, and $1 \%$ levels, respectively. 
All of the empirical results above support the hypotheses that the active participation of students creates positive perceptions of accounting, and this perception helps learning in introductory accounting courses.

\subsection{Additional Test: Structural Equation Model}

The structural equation model could also be used to test the hypotheses. The results using AMOS statistical software are shown in Tables 11 and 12. All paths through PP1 and PP2 were significant, supporting the hypotheses in agreement with the regression results.

Table 11. Paths through PP1. H-hypothesis.

\begin{tabular}{cccccccc}
\hline H & Path & Expected Sign & Coefficient & SE & C.R. & $p$-Value & \\
\hline H1 & AP $\rightarrow$ PP1 & + & 0.9 & 0.095 & 9.496 & 0.00 & Accepted \\
\hline \multirow{3}{*}{ H2 } & PP1 $\rightarrow$ AL1 & + & 0.971 & 0.101 & 9.593 & 0.00 & Accepted \\
& PP1 $\rightarrow$ AL2 & + & 0.82 & 0.099 & 8.318 & 0.00 & Accepted \\
& PP1 $\rightarrow$ AL3 & + & 0.83 & 0.099 & 8.418 & 0.00 & Accepted \\
\hline
\end{tabular}

Table 12. Paths through PP2.

\begin{tabular}{cccccccc}
\hline $\mathbf{H}$ & Path & Expected Sign & Coefficient & SE & C.R. & $p$-Value & \\
\hline $\mathrm{H} 1$ & $\mathrm{AP} \rightarrow \mathrm{PP} 2$ & + & 0.608 & 0.107 & 5.693 & 0.00 & Accepted \\
\hline \multirow{3}{*}{$\mathrm{H} 2$} & $\mathrm{PP} 2 \rightarrow \mathrm{AL} 1$ & + & 1.175 & 0.179 & 6.564 & 0.00 & Accepted \\
& $\mathrm{PP} 2 \rightarrow$ AL2 & + & 0.87 & 0.154 & 5.635 & 0.00 & Accepted \\
& $\mathrm{PP} 2 \rightarrow$ AL3 & + & 1.27 & 0.174 & 7.281 & 0.00 & Accepted \\
\hline
\end{tabular}

\section{Conclusions and Discussion}

Accounting education with too much focus on technical details generates unfavorable perceptions of students toward accounting and lowers their interests in further study. The students' notion that accounting is "number crunching" or "bean counting" should be eradicated to change their negative perceptions. This is because stereotypical negative perception has an impact on learning process and outcome, and then on choice of academic major and career. This research tested whether students favorably changed their perception of accounting when they actively participated in board game activities in class, and whether their activities were helpful for learning accounting.

Many previous researches suggested that instructors should make an effort to increase interest and involvement of accounting students, and that it is important to promote the ability to apply their knowledge to various situations more than the ability to simply understand GAAP (Generally Accepted Accounting Principles) $[4,8,11]$. On the other hand, some prior studies reported that there was no difference between traditional teaching methods and modern pedagogy in accounting education $[15,21,24]$. Most students who are familiar with traditional pedagogy recognize that they have to devote enough time and effort for learning in active learning. Furthermore, students prefer to solve multiple-choice exercises to prepare for CPA (Certified Public Accountant) examinations using traditional methods, which is consistent with their needs. These outcomes imply that students like to learn only delivered knowledge from instructors, or passively resolve the problems that instructors present.

If students take active part in team activities, they will gain positive perceptions of the learning objectives and achieve higher learning effects. In this research, we found ways to change the negative perception of students. This is quite meaningful since perception itself greatly affects student attitude toward accounting learning. Thus, this study suggests a learning method based on a board game making students interested in accounting. This approach is not widely used but it can be effective, inducing students to get a hold on accounting knowledge through playing an interesting game. 
Empirical results supported our hypotheses. Firstly, active participation in the game activities generated positive perceptions of accounting. The board game played was perceived as part of the learning activities, not as a simple fun activity for students' attention. Secondly, a positive perception of accounting resulted in effective learning of accounting concepts, systems, and reports.

There are multiple contributions of this work. Firstly, this study showed that instructors need to create learning environments where students can actively participate in class activities such as game playing, thereby positively changing their perception of the subject, achieving effective learning. Secondly, the mediating effect of perception to learning documented in this study implies that instructors need to take into account the impact of activities in or out of classes on the perception of subjects, as well as on specific knowledge learning when designing activities. These issues need to be further investigated in other future studies.

This study had a limitation in that samples were limited to students at two universities in one semester. This indicates that we need to extend sample size for generalization and enhancing validity in future study. Another limitation was that this work did not use a control group without game activities for comparison in perception and learning effects, since within-group analysis, not cross-group analysis, was done.

Author Contributions: Conceptualization and data collection, Y.-H.P.; data curation, formal analysis, and original draft, J.-H.K.; writing and review, T.-Y.P.

Funding: This research received no external funding.

Acknowledgments: We really appreciate the constructive comments and meaningful suggestions of the anonymous reviewers to improve the research quality.

Conflicts of Interest: The authors declare no conflict of interest.

\section{References}

1. Barrows, H.S. Problem-based learning in medicine and beyond a brief overview. New Dir. Teach. Learn. 1996, 1996, 3-12. [CrossRef]

2. Kaklauas, A.; Banaitis, A.; Ferreira, F.A.; Ferreira, J.; Amaratunga, D.; Lepkova, N.; Ubarte, I.; Banaitiene, N. An evaluation system for University-Industry partnership sustainability: Enhancing options for entrepreneurial Universities. Sustainability 2018, 10, 119. [CrossRef]

3. Kim, S.A.; Ryoo, H.Y.; Ahn, H.J. Student customized creative education model based on open innovation. J. Open Innov. Technol. Mark. Complex. 2017, 3, 6. [CrossRef]

4. Haywood, M.E.; McMullen, D.A.; Wygal, D.E. Using games to enhance student understanding of professional and ethical responsibilities. Issues Account. Educ. 2004, 19, 85-99. [CrossRef]

5. Knechel, W.R. Using a business simulation game as a substitute for a practice set. Issues Account. Educ. 1989, $4,411-424$.

6. Koo, J.H.; Park, Y.H. Accounting Principle Teaching Case Based on the Activities Learning. Korean Account. J. 2015, 24, 45-70. (In Korean)

7. Park, Y.H.; Koo, J.H.; Paik, T. Accounting Principles Education Using a Board Game. Korean Account. J. 2016, 25, 435-462. (In Korean)

8. Warren, D.W.; Young, M.N. Integrated accounting principles: A best practices course for introductory accounting. Issues Account. Educ. 2012, 27, 247-266. [CrossRef]

9. Geiger, M.A.; Ogilby, S.M. The first course in accounting: students' perceptions and their effect on the decision to major in accounting. J. Account. Educ. 2000, 18, 63-78. [CrossRef]

10. Braun, K.W.; Seller, R.D. Using a "daily motivational quiz" to increase student preparation, attendance, and participation. Issues Account. Educ. 2012, 27, 267-279. [CrossRef]

11. MaGowan, S. Going beyond the numbers in teaching financial accounting: The newsletter as an assignment option. Issues Account. Educ. 2012, 27, 1095-1117. [CrossRef]

12. Mladenovic, R. An investigation into ways of challenging introductory accounting students' negative perceptions of accounting. Account. Educ. 2000, 9, 133-155. [CrossRef] 
13. Cook, E.D.; Hazelwood, A.C. An active learning strategy for the classroom: "Who wants to win some mini Chips Ahoy?". J. Account. Educ. 2002, 20, 297-306. [CrossRef]

14. Paik, T. Cases of Problem-Based Learning in Cost and Management Accounting Education. Korean Account. J. 2010, 19, 61-89. (In Korean)

15. Hwang, N.C.R.; Lui, G.; Tong, M.Y.J.W. Cooperative learning in a passive learning environment: A replication and extension. Issues Account. Educ. 2008, 23, 67-75. [CrossRef]

16. Bonwell, C.C.; Eison, J. Active Learning: Creating Excitement in the Classroom. 1991 Ashe-Eric Higher Education Report (No. 1); The George Washington University School of Education and Human Development: Washington, DC, USA, 1991.

17. Lancaster, K.A.S.; Strand, C.A. Using the team-learning model in a managerial accounting class: An experiment in cooperative learning. Issues Account. Educ. 2001, 16, 549-567. [CrossRef]

18. Kwon, J.E.; Woo, H.R. The impact of flipped learning on cooperative and competitive mindsets. Sustainability 2018, 10, 79. [CrossRef]

19. Hwang, N.C.R.; Lui, G.; Tong, M.Y.J.W. An empirical test of cooperative learning in a passive learning environment. Issues Account. Educ. 2005, 20, 151-165. [CrossRef]

20. Lightner, S. Accounting Education and Participatory Group Dynamics. Coll. News Views 1981.

21. Opdecam, E.; Everaert, P. Improving student satisfaction in a first-year undergraduate accounting course by team learning. Issues Account. Educ. 2012, 27, 53-82. [CrossRef]

22. Cohen, J.; Cohen, P.; West, S.G.; Aiken, L.S. Applied Multiple Regression/Correlation Analysis for Behavior Science, 3rd ed.; Lawrence Erbaum Associates: Mahwah, NJ, USA, 2003.

23. Choi, J.; Park, J. The Relationship Among Inter-Organizational Factors, Inter-Organizational Cost Management, and Organizational Performance. Korean J. Manag. Account. Res. 2010, 10, 1-36. (In Korean)

24. Ravenscroft, S.; Buckless, F.; McCombs, G.; Zuckerman, G. Incentives in student team learning: An experiment in cooperative group learning. Issues Account. Educ. 1995, 10, 97-109.

(C) 2019 by the authors. Licensee MDPI, Basel, Switzerland. This article is an open access article distributed under the terms and conditions of the Creative Commons Attribution (CC BY) license (http://creativecommons.org/licenses/by/4.0/). 